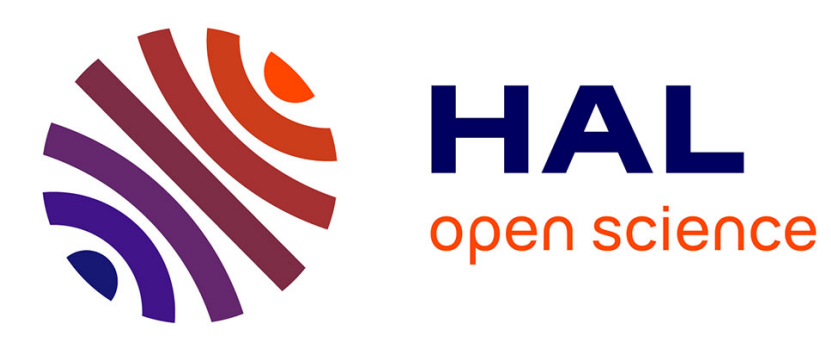

\title{
Barium Diketonates as Precursors for HTSC Thin Films: Structure and Properties
}

\author{
A. Drozdov, S. Troyanov
}

\section{To cite this version:}

A. Drozdov, S. Troyanov. Barium Diketonates as Precursors for HTSC Thin Films: Structure and Properties. Journal de Physique IV Proceedings, 1995, 05 (C5), pp.C5-373-C5-377. 10.1051/jphyscol:1995544 . jpa-00253871

\section{HAL Id: jpa-00253871 https://hal.science/jpa-00253871}

Submitted on 1 Jan 1995

HAL is a multi-disciplinary open access archive for the deposit and dissemination of scientific research documents, whether they are published or not. The documents may come from teaching and research institutions in France or abroad, or from public or private research centers.
L'archive ouverte pluridisciplinaire HAL, est destinée au dépôt et à la diffusion de documents scientifiques de niveau recherche, publiés ou non, émanant des établissements d'enseignement et de recherche français ou étrangers, des laboratoires publics ou privés. 


\title{
Barium Diketonates as Precursors for HTSC Thin Films: Structure and Properties
}

\author{
A. Drozdov and S. Troyanov \\ Moscow State University, Department of Chemistry, 119899 Moscow, Vorobjevy Gory, Russia
}

\begin{abstract}
Homoligand and mixed ligand barium diketonate complexes have been synthesized and characterized by X-ray structure determination. Homoligand complexes with dipivaloylmethane hexafluoroacetone and pivaloyltrifluoroacetone have oligigomeric or polymeric structure. The mixed complexes with additional anionic ligands $\left(\mathrm{Cl}^{-} \mathrm{OH}^{-}\right.$, Piv- $)$form pentanuclear complexes. The structures of the mixed ligand complexes with Lewis bases contain either mono or dinuclear chelates. Deoligomerization is accompanied by a decrease of the sublimation temperature and improves a storage stability of barium complexes used in MOCVD process for production of HTSC films.
\end{abstract}

\section{INTRODUCTION}

One of the problems with the MOCVD of superconducting thin films is the low volatility and thermal stability of the barium chelates used as precursors. Structural investigations revealed that the reason for the poor thermal stability and relatively high sublimation temperatures of the homoligand barium $\beta$ diketonates is their oligomeric nature. The low coordination numbers of barium atoms in these compounds (six or seven) make them sensitive to traces of water or carbon dioxide. High chemical reactivity of such complexes is also responsible for a low reproducibility of their volatility at elevated temperatures. One of the ways to decrease a degree of oligomerization and, hence, to improve the volatility, thermal stability and to prolong a storage period, is to prepare mixed ligand complexes containing, in addition to the $\beta$-diketonate, different neutral or anionic ligands [1].

\section{EXPERIMENTAL}

\subsection{Synthesis}

The preparation of homoligand chelate complexes $\mathrm{BaL}_{2}(\mathrm{HL}=\mathrm{Hthd}, 2,2,6,6$-tetramethylheptane-3,5dione [2-4]; Hhfa, 1,1,1,5,5,5-haxafluoroacetylacetone [5]; Hpta, 1,1,1-trifluoro-5,5dimethylhexanedione, or pivaloyltrifluoroacetone [6]) were carried out using $\mathrm{Ba}$ metal and diketone or by vacuum sublimation from the mixed ligand complexes. $B_{2} L_{2} \cdot$. 
The mixed ligand diketonates with $\mathrm{N}$ - and $\mathrm{O}$-Lewis bases were obtained by dissolving of $\mathrm{Ba}$ metal in diketone in the presence of Lewis base or using the reaction between $\mathrm{Ba}(\mathrm{OH})_{2}$ (or barium salt) and alkali derivative of diketone in the presence of additional ligand [7-10].

\subsection{Crystal structure determination}

The crystal structure of complexes have been investigated by single crystal X-ray diffraction. The crystals were placed in sealed glass capillaries because the most of compounds were more or less sensitive to air. Diffraction data were collected on Enraf Nonius CAD-4 or Siemens P3/PC diffractometers using $M o-K_{\alpha}$ radiation with graphite monochromator.

The crystallographic calculations were performed using SHELXTL PLUS or SDP program packages using direct and Patterson methods. For most structures, all non hydrogen atoms were refined anisotropically to $\mathbf{R}$ values in the range of $0.05-0.08$. Partial disorder of tret-butyl groups around a $\mathrm{C}$ $\mathrm{C}\left(\mathrm{CH}_{3}\right)_{3}$ axis has been found in many cases.

\section{RESULTS AND DISCUSSION}

\subsection{Homoligand complexes}

Both crystalline forms of $\mathrm{Ba}(\text { thd })_{2}$ (prepared from solution and from the gas phase) are actually tetranuclear complexes $\mathrm{Ba}_{4}$ (thd) 8 with different packing of molecules (Fig. 1) [2-4]. Other coordination of $\beta$-diketonate ligand has been found in the tetranuclear $\mathrm{Ba}_{4}(\mathrm{pta})_{8}$ due to additional $\mathrm{Ba}$...F interactions at the distances $2.87-3.16 \AA$ (Fig. 2) [6]. Tetranuclear complexes possess relatively high volatility but they are very sensitive to moisture and carbon dioxide due to lower coordination numbers of $B$ a atoms in respect to oxygen. In contrary, complex $\mathrm{Ba}(\mathrm{hfa})_{2}$ with fully fluorinated ligand possesses a chain polymeric structure with additional $\mathrm{Ba}$...F bonding at 2.76-3.09 $\AA$ [5], that results in the low volatility of this substance and in the formation of $\mathrm{BaF}_{2}$ by its thermal decomposition.

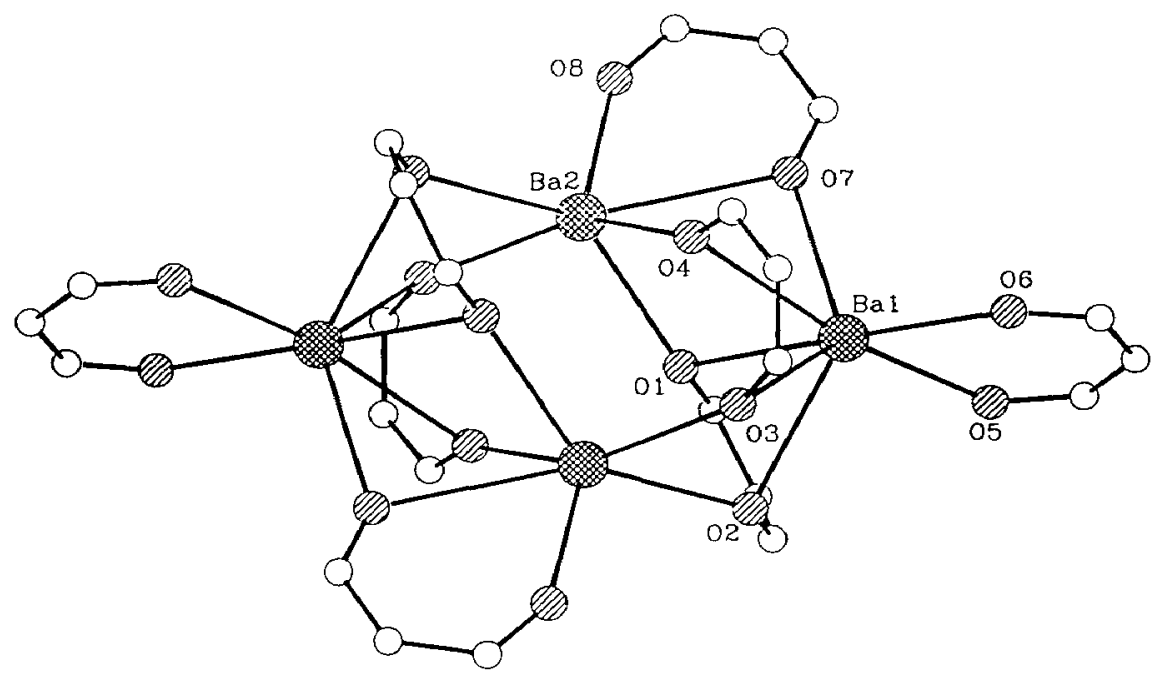

Figure 1: Tetranuclear molecule of $\mathrm{Ba}_{4}(\text { thd })_{8}$. tret-Butyl groups are omitted for clarity. 


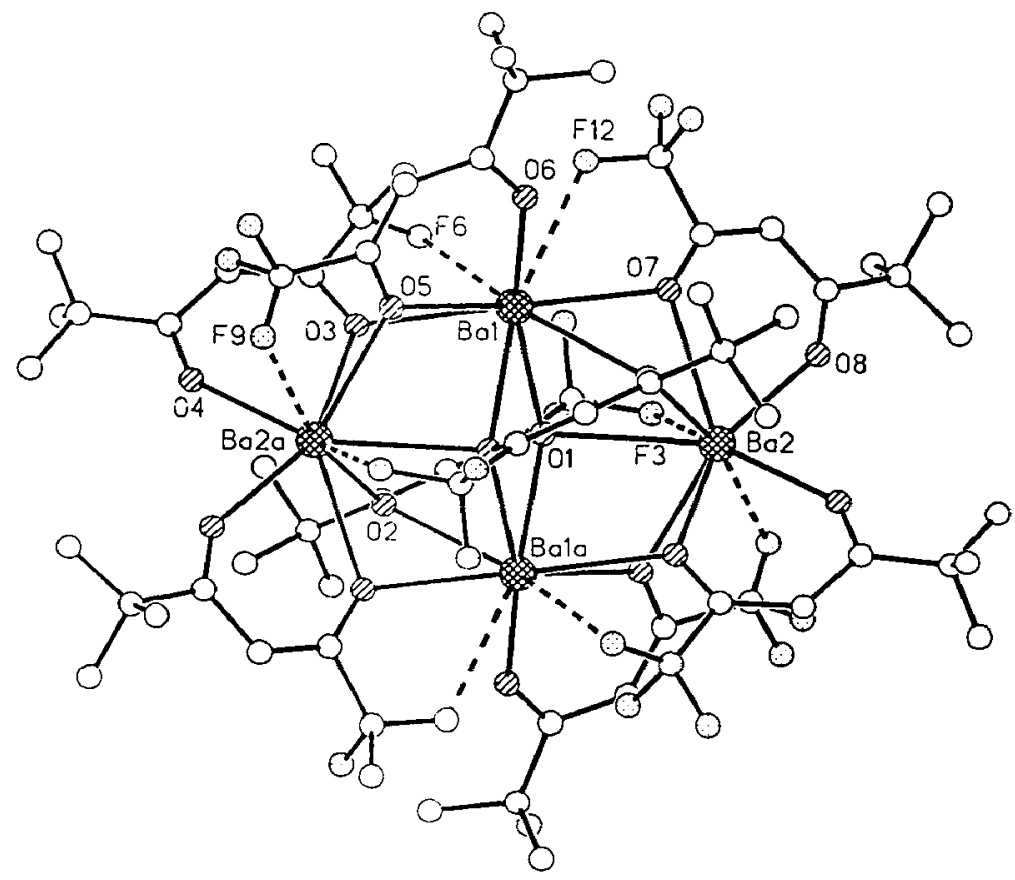

Figure 2: Tetranuclear molecule of $\mathrm{Ba}_{4}(\mathrm{pta})_{8}$. The dashed lines show the Ba..F interactions

\subsection{Mixed ligand complexes}

3.2.1 Anionic additional ligand. The use of this type of additional ligands results in increase of the oligomerization degree compared with homoligand complexes. Thus, the mixed ligand complexes containing anionic ligand such as $\mathrm{Cl}^{-}, \mathrm{OH}^{-}$, and $(\mathrm{CH})_{3} \mathrm{COO}^{-}$(pivalate) consist of pentanuclear species. $\mathrm{Ba}_{5}$ (thd) ${ }_{9} \mathrm{Cl}\left(\mathrm{H}_{2} \mathrm{O}\right)_{7}$ (Fig. 3) [7], $\mathrm{Ba}_{5}$ (thd $)_{9}(\mathrm{OH})\left(\mathrm{H}_{2} \mathrm{O}\right)_{3}$ [11], and $\mathrm{Ba}_{5}$ (thd) $)_{9}$ (piv) [3], respectively. As expected, these compounds do not show any increase of volatility or improvement of storage sability compared with correspouding homoligand complexes.

3.2.2 Neutral additional ligand. Barium diketonates with neutral Lewis bases such as $\mathrm{H}_{2} \mathrm{O}$. 2.2 dipyridyl, diglyme, tetraglyme, 1,10-phenantroline and others have oligomerization degree less than those in homoligand chelates. Their structures contain dinuclear species $\left[\mathrm{Ba}_{2}(\text { thd })_{4}\left(\mathrm{H}_{2} \mathrm{O}_{4}\right]_{3}\left(\mathrm{H}_{2} \mathrm{O}\right.\right.$ (Fig. 4) [8], [Ba 2 (thd $\left.)_{4}(\text { dipy) })_{2}\right][12],\left[\mathrm{Ba}(\text { thd })_{2}(\text { diglyme }]_{2}\left(\mu-\mathrm{H}_{2} \mathrm{O}\right)\right.$ [1], or mononuclear ornes: $\mathrm{Ba}$ (thd $)_{2}$ (tetraglyme) [13], Ba(thd) $)_{2}$ (Phen) $)_{2}$ [12], Ba(pta) $)_{2}$ (tetraglyme) (Fig. 5) [9]. It is of interest that both $\mathrm{Ba}(\mathrm{hfa})_{2}\left(\mathrm{H}_{2} \mathrm{O}\right)$ [10] and $\mathrm{Ba}(\mathrm{pta})_{2}$ possess a chain polymeric structure very similar to that of $\mathrm{Ba}(\mathrm{hfa})_{2}\left(\mathrm{Et}_{2} \mathrm{O}\right)_{0.5}$ due to the additional Ba...F contacts. 


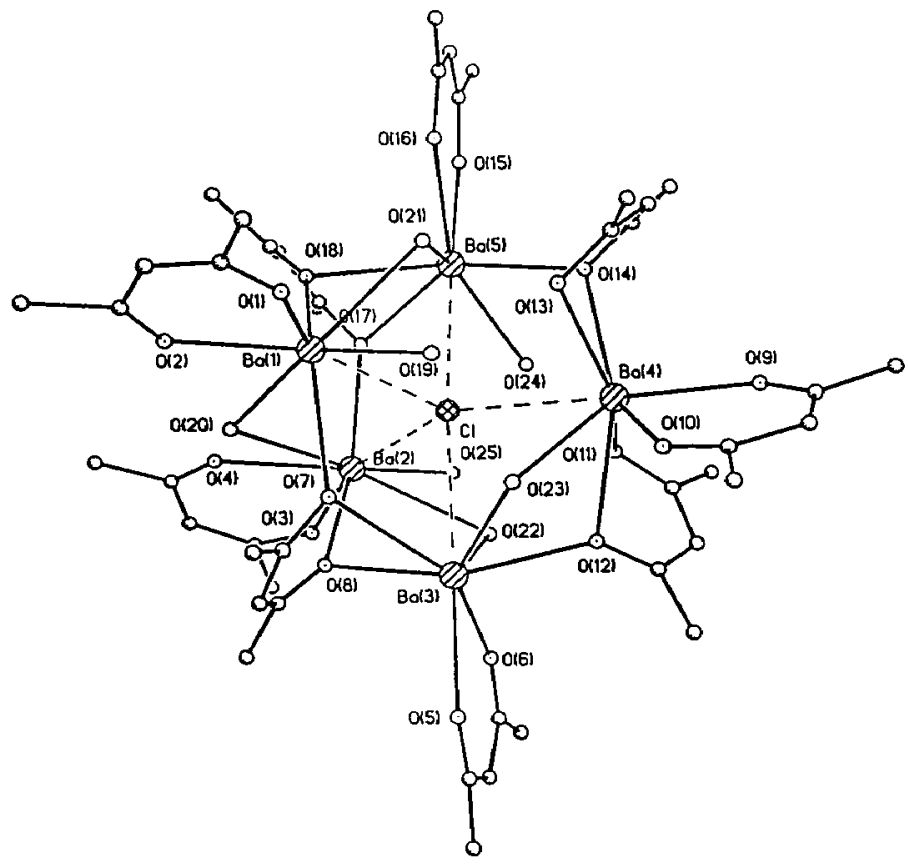

Figure 3: Pentaluclear molecule of $\left[\mathrm{Ba}_{5}(\text { thd })_{9} \mathrm{Cl}\left(\mathrm{H}_{2} \mathrm{O}\right)_{7}\right.$.

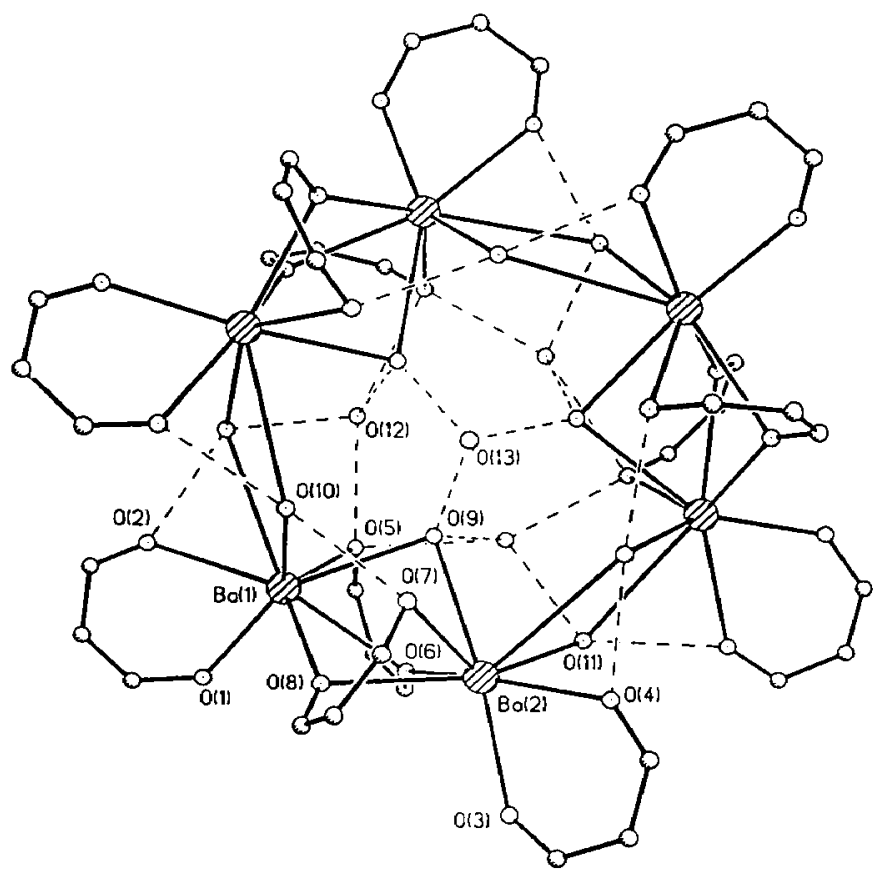

Figure 4: Structure of $\left[\mathrm{Ba}_{2}(\text { thd })_{4}\left(\mathrm{H}_{2} \mathrm{O}\right)_{4}\right]_{3}\left(\mathrm{H}_{2} \mathrm{O}\right)$ 


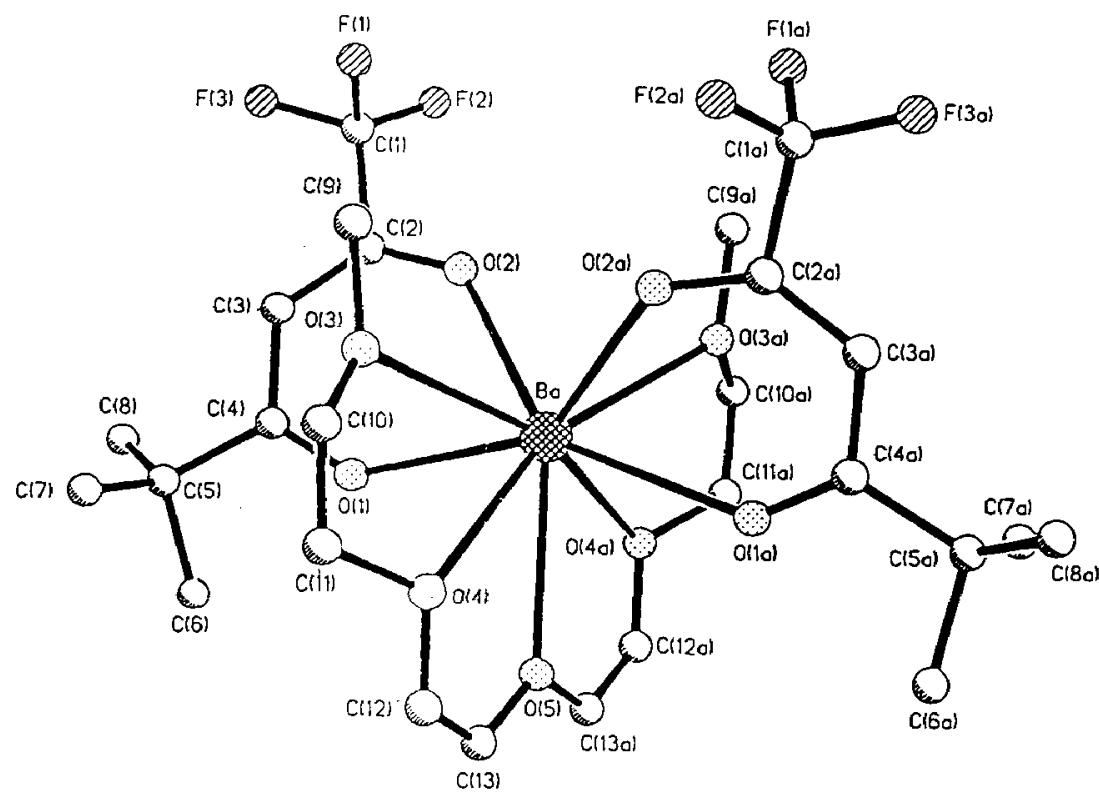

Figure 5: Mononuclear complex $\mathrm{Ba}(\mathrm{pta})_{2}$ (tetraglyme).

Low nuclearity of the adducts with neutral ligands accompanied by relatively high $\mathrm{CN}$ of $\mathrm{Ba}$ results in a slight decrease of sublimation temperature diminishes a sensibility to air and also leads to an appreciable improvement of a storage stability.

\section{References}

[1] Drozdov A., Kuzmina N., Troyanov and Martynenko L., Mater. Sci. Engng B18 (1993) 139- 140.

[2] Gleizes A., Sans-Lenain S. and Medus D., Compt. Rend. Sci. Paris, Serie II 313 (1991) 761-766.

[3] Drozdov A. and Troyanov S., Polyhedron 11 (1992) 2877-2882.

[4] Gleizes A., Drozdov A., Troyanov S., Koord. Khim. 20 (1994) 922-927.

[5] Drozdov A. and Troyanov S., Chem. Commun. (1993) 1619-1621.

[6] Drozdov A., Troyanov and Pisarevsky A., Polyhedron 14 (1995), submitted; see also the paper of the same authors in this issue.

[7] Drozdov A., Troyanov S., Pisarevsky A. and Struclkov Yu., Polyhedron 13 (1994) 1445- 1452.

[8] Drozdov A.A., Troyanov S., Pisarevsky A. and Struchkov Yu., Polyhedron 13 (1994) 2459-2461.

[9] Drozdov A., Kupriyanova G., Kuzmina N. et al, Koord. Khim. 20 (1994).

[10] Bradley D., Hasan M., Hursthouse M. et al, Chem. Commun. (1992) 575-576.

[11] Turnpseed S., Barkley R. and Sievers R., Inorg. Chem. 30 (1991) 1164-1170.

[12] Drozdov A., Troyanov S., Kuzmina N. et al, J. Phys. IV, Coll. C3 3 (1993) 379-384.

[13] Drozdov A. and Troyanov S., Koord. Khim. 20 (1994) 171-174 